\title{
Beneficiation of Iranian magnesite ores by reverse flotation process and its effects on shaped and unshaped refractories properties
}

\author{
S ASLANI", H R SAMIM BANI HASHEMI ${ }^{\dagger}$ and F ARIANPOUR ${ }^{\dagger}$ \\ School of Mining Engineering, Faculty of Engineering, University of Tehran, 11365, Amir Abad, Tehran, Iran \\ ${ }^{\dagger}$ School of Metallurgy and Materials Engineering, Iran University of Science and Technology, 16844, Narmak, Tehran, Iran
}

MS received 24 June 2009; revised 19 October 2009

\begin{abstract}
The primary aim of this study is the beneficiation of magnesite ores from eastern part of Iran by reverse flotation process. For this purpose, the mineralogical and microstructural characteristics of the as-received and the processed ores from Iranian Afzal Abad mine were established. The liberation degree of ore was estimated at about $75 \mu \mathrm{m}$. Then the as-received ore and the processed one were dead burnt to produce magnesia aggregates. These aggregates were used for production of shaped and unshaped refractories. Bricks and monolithic ramming mixes which were made from these aggregates were analysed and their mechanical and physical properties, studied. The results of this investigation showed that the application of reverse flotation process on the magnesite ore of eastern part of Iran causes an acceptable reduction on the amount of its siliceous inclusions, so that this type of the processed magnesia is suitable for utilization in the refractory industries. The magnesia produced from the original calcined ore was not suitable for this industry due to the presence of unacceptable amount of siliceous inclusions, which make its properties very poor.
\end{abstract}

Keywords. Magnesite; geology; beneficiation; reverse flotation; refractories.

\section{Introduction}

Magnesite $\left(\mathrm{MgCO}_{3}\right)$ is the major source of magnesium oxide and is the most important raw material utilized in refractory industries for manufacturing of basic refractories, having a high corrosion resistance in the presence of basic slags, dusts and fumes in metallurgy, chemical and ceramic industries (Spencer 1978; Ryder 1993). Shaped and unshaped magnesite refractories have been used over many years as high strength hot-face refractories in a wide range of furnaces. They have important applications where a very high degree of refractoriness or resistance to basic environments is required, such as steel making vessels and rotary cement kilns (Jankanovic and Vumberkovic 1992; Shikano 1998; Palco and Riguad 2002). Grain size and boundaries, impurities and/or additives, porosity, sintering temperature and shaping practice, play an important role in controlling many physical, mechanical and chemical properties of magnesia-based refractories (Palco and Riguad 1993; Aksel et al 2005; Othman and Khalil 2005). Magnesia $(\mathrm{MgO})$ is mostly produced by calcination of magnesite $\left(\mathrm{MgCO}_{3}\right)$. When magnesite is heated up to 1400 $1800{ }^{\circ} \mathrm{C}$, the carbonates are removed as carbon dioxide and the magnesium oxide is produced (Birchal et al 2000).

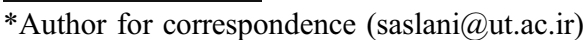

The demand for high purity magnesium oxide has increased considerably in recent years and it has become necessary to develop more efficient processes for magnesite separation from associated gangue minerals to obtain higher grade magnesite (Ahmed et al 1990; Nishino 1999). Gravity separation and flotation are two major methods used for magnesite ore beneficiation. Gravity separation is employed for coarse size (i.e. $>1 \mathrm{~mm}$ ) and flotation is commonly used for fine magnesite separation, particularly when a high grade of magnesite concentrate is needed (Santana and Peres 2001). The dissolution characteristic of mineral has significant effects on flotation. It affects the solution composition, surface charge and its floatability (Chen and Tao 2004). Magnesite can be classified into salt type minerals in terms of its flotation response. It is floated with anionic type collectors during direct flotation, whereas impurities are floated with both anionic and cationic type collectors during reverse flotation. Regulation of $\mathrm{pH}$ during anionic flotation is said to be extremely crucial and some alkali ion addition, i.e. $\mathrm{Na}_{2} \mathrm{CO}_{3}$, is necessary for this process due to its $\mathrm{pH}$ increasing and precipitation properties (Ozkan 2002; Chen and Tao 2004). Magnesium carbonates were characterized by the dissolution of the lattice ions and subsequent complexation, hydrolysis, and adsorption of the dissolved species. The complex interactions between these processes determine the interfacial properties of magnesium carbonates 


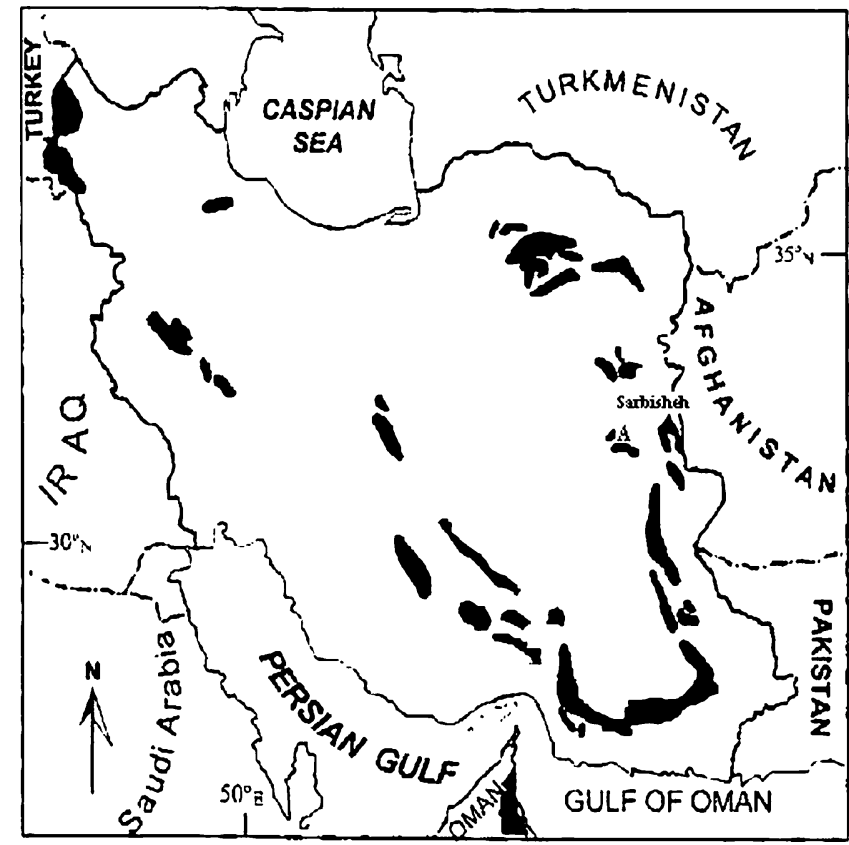

Figure 1. Index map showing the locations of major Iranian ophiolites and the location of Afzal Abad magnesite deposit studied in this investigation (A: Afzal Abad mine).

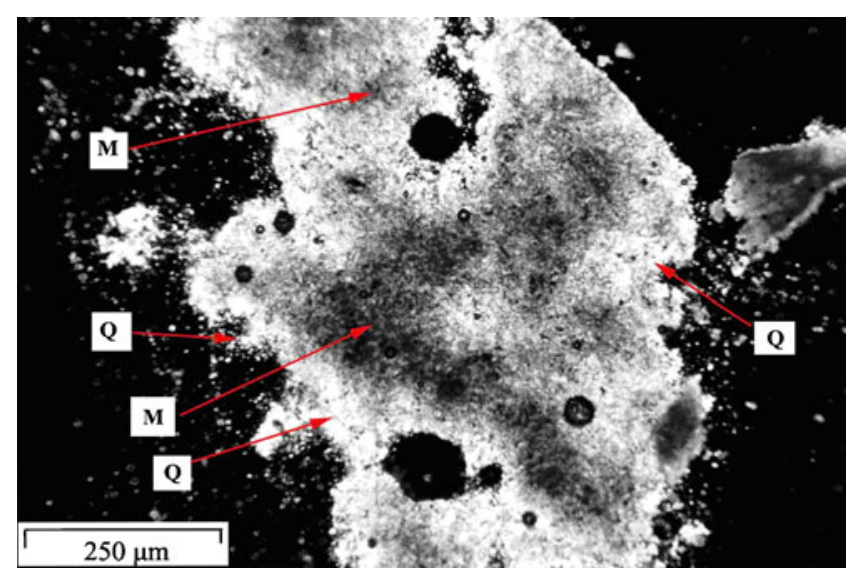

Figure 2. Polarized light micrograph of a magnesite particle containing cryptocrystalline quartzite.

and thereby the efficiency of flotation. The surface properties of magnesite mineral, silicate, quartz and various iron minerals were known to be different. They can be readily separated by flotation. However, magnesite and dolomite $\left(\mathrm{CaMg}\left(\mathrm{CO}_{3}\right)_{2}\right)$ have the same crystal structure, similar surface property, and sparingly soluble nature that tend to reduce the difference in their flotation behaviour.

Ophiolite complexes of Iran are a part of Tethyan ophiolite belts of the Middle East which link to other Asian ophiolites such as Pakistan in the east as well as to ophiolites in the Mediterranean region such as Turkish, Troodos Greek, and east Europe in the west. These

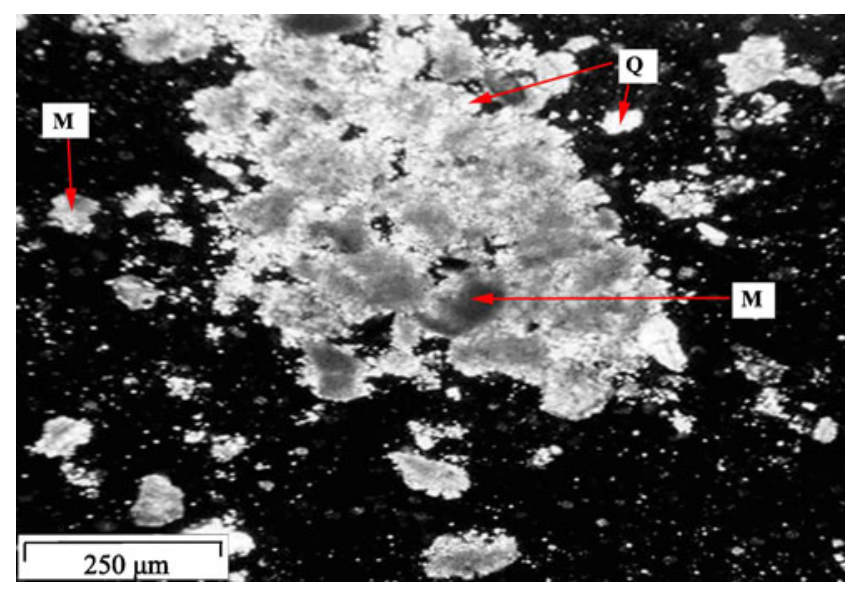

Figure 3. Polarized light micrograph of free magnesite particles after crushing $(75 \mu \mathrm{m})$ accompanied by quartzite particles.

ophiolites rest as giant thrust sheets upon a continental substrate (Dolatabadi 2000). As is shown in figure 1 (Yaghubpur and Hassannejad 2006), the magnesite deposits in Iran are very widely distributed and can be divided into 3 parts. First part is located in ophiolites in Zagros belt from northern west to southern east of Iran. The second part is located in Alborz belt from Shahrud and Sabzevar to Southern Khorasan, and the third is placed around the Lut block (Dolatabadi 2000).

The most important magnesite deposits in Iran are located in the eastern part of Iran. A narrow belt of ophiolitic rocks is located between Qaen and north of Iranshar (Hoseini 1988). In this part the magnesite resources can be found in three forms based on their texture and structure according to the following: (a) sedimentary magnesite in two different forms as magnesites containing different salts in evaporation areas and sedimentary magnesite produced from erosion, slow sedimentation and deposition, (b) veined and bulk magnesite in crystalline and cryptocrystalline forms and (c) magnesite in weathered ultra basic rocks and serpentines in the form of cauliflower type, shallow veined and stockwerk.

The most important magnesite resources in this part have veined and bulk lens shapes in structural fractures and faults

Table 1. Calculated mean specific gravities.

\begin{tabular}{lcc}
\hline Samples & $\begin{array}{l}\text { Apparent specific } \\
\text { gravity }\left(\mathrm{gr} / \mathrm{cm}^{3}\right)\end{array}$ & $\begin{array}{l}\text { Real specific } \\
\text { gravity }\left(\mathrm{gr} / \mathrm{cm}^{3}\right)\end{array}$ \\
\hline AR & $1 \cdot 49$ & $2 \cdot 81$ \\
AP & $1 \cdot 62$ & 3 \\
AR1750 & - & $3 \cdot 1$ \\
AP1750 & - & $3 \cdot 3$ \\
MR & - & $3 \cdot 3-3 \cdot 4$
\end{tabular}

AR: As-received sample; AP: processed sample; AR1750: as-received sample heated at $1750^{\circ} \mathrm{C}$ for $2 \mathrm{~h}$; AP1750: processed sample heated at $1750{ }^{\circ} \mathrm{C}$ for $2 \mathrm{~h}$; MR: reference (commercial) magnesia sample 
Table 2. Mean chemical analysis of magnesite samples (wt. \%).

\begin{tabular}{lllllll}
\hline Samples & $\mathrm{MgO}$ & $\mathrm{CaO}$ & $\mathrm{SiO}_{2}$ & $\mathrm{Fe}_{2} \mathrm{O}_{3}$ & L.O.I. & $\mathrm{CaO} / \mathrm{SiO}_{2} \mathrm{ratio}$ \\
\hline $\mathrm{AR}$ & 41.85 & 2.06 & 6.16 & 0.46 & 46.76 & - \\
$\mathrm{AP}$ & 44.28 & 2.48 & 5.58 & 0.78 & 46.85 & - \\
$\mathrm{AR} 1750$ & 82.69 & 3.56 & 9.28 & 1.24 & - & 0.38 \\
$\mathrm{AP} 1750$ & 88.15 & 2.39 & 3.54 & 1.53 & - & 0.67 \\
$\mathrm{MR}$ & 91 & 3.5 & 4.5 & 1 & - & 0.77 \\
\hline
\end{tabular}

Table 3. Flotation test parameters.

\begin{tabular}{llll}
\hline Flotation machine & Denver Sub2A & Impeller speed & $1200 \mathrm{rpm}$ \\
Amount of sample & $200 \mathrm{~g}$ per test & Solid/liquid ratio & $20 \%$ \\
Water source and type & Tap water, hard & Temperature & Ambient \\
Collectors & Armoflot 17,18 & Flotation time & About 5 min \\
Frother & $\mathrm{MIBC}$ & pH regulation & $9-10$ with NaOH HCl addition \\
Depressant & 2000 gpt Na $\mathrm{Si}_{2} \mathrm{O}_{3}$ at $5 \%$ conc. & Activator & 300 gpt kerosene $(5 \%$ conc. $)$ \\
\hline
\end{tabular}

inside the host ultrabasic serpentanized rocks. Also in some regions crystalline veined magnesite can be found (Dolatabadi 2000). In this paper, the mineralogical, microstructural and other properties of sintered magnesia grains and shaped and unshaped refractories made of as-received and reverse flotation processed ores from Iranian Afzal Abad mine were investigated.

\section{Experimental}

\subsection{Mine selection and characterization}

In this study, Afzal Abad mine was selected as representative mine from about 50 Iranian magnesite mines for sampling and investigations. This mine is located at $195 \mathrm{~km}$ south west of Sarbisheh city and its reserve is estimated at about 30000 tonnes. This mine consists of eosin flishes and host serpentanized ultrabasic rocks in depth and includes two different parts. The first is Southern Afzal Abad which contains high purity magnesite ores and negligible iron. The second is Northern Afzal Abad which contains lower purity magnesite ores and the interference of magnesite ores by the other rocks can also be found. The major impurities in this mine consist of dolomite, quartzite and calcite and therefore, to produce a high purity magnesite, the ore needs to be processed properly (Golestani-Fard 1997; Dolatabadi 2000).

The sampling was done by selecting a profile in the northern part of the mine. The sampling interval was $30 \mathrm{~m}$ and every sample weighed $3-4 \mathrm{~kg}$. Crushing and milling were performed for determination of grindability of samples including crushing time, screen analysis, gravity, densities and work index measurements. The crushing process consisted of two open cycle jaw crushing steps and one closed circuit roll crushing step to reach the desired particle size distribution. A standard procedure for sampling was followed according to literature (Covacic and Clarke 1991). Then the samples were divided by rifle to prepare several $1 \mathrm{~kg}$ batches for performing flotation process and other tests.

Petrographic thin and polished sections were provided from the Afzal Abad samples to study and identify minerals using polarizing and reflective microscopes. Textural features of the samples showed that the clastic fabric is predominant in which the grain size varied from $0 \cdot 1+10 \mathrm{~cm}$. Clasts as well as groundmasses are mainly carbonate in composition, so that magnesite and dolomite are minor. Also, some very fine grains $(<100 \mu \mathrm{m})$ of clay and silicate minerals, including illite, kaolinite and olivine were identified as impurities. The latter can be concluded as possible production of the hydrothermal alteration occurring in ultramafic sequence of the region. This process could be the main cause for originating of secondary $\mathrm{Fe}-\mathrm{Mg}$ mafic minerals which got deposited in fractures and dissolved spaces. However, dispersion in suit quartz grains with $\sim 50 \mu \mathrm{m}$ in size were observed in all samples. In general, the petrographic study implied that some dolomitic samples were partly altered to magnesium. It recognized that the studied magnesium deposit resembled the well known Turkish magnesium type. It has also been shown that $75 \mu \mathrm{m}$ is a proper estimation for liberation degree of minerals (figures 2 and 3).

The optimum milling time of the ore was selected according to the liberation size of the constitutional minerals. It was decided to reduce the mineral sizes to $75 \mu \mathrm{m}$. Therefore, milling the sample was carried out until a D80 of $75 \mu$ was reached. The work index for this sample was equal to $16 \cdot 37(\mathrm{kwh} / \mathrm{t})$. The apparent specific gravity values were determined by measuring the weight and volume of the samples in a scaled cylinder. The real specific gravity was measured by picnometry. The results are 
Table 4. Batch composition of refractory brick and ramming mix samples.

\begin{tabular}{llcc}
\hline & & Brick & $\begin{array}{l}\text { Ramming } \\
\text { mix }\end{array}$ \\
\hline Magnesia & $1-4 \mathrm{~mm}$ & 38 & 40 \\
aggregates & $<1 \mathrm{~mm}$ & 30 & 30 \\
(balanced) & $<0 \cdot 150 \mathrm{~mm}$ & 32 & 30 \\
Ball clay & SQ (UK) & - & 4 \\
Microsilica & Iran ferrosilica Co. & - & 2 \\
Binder & Budapur phosphate binder & - & 2 \\
& (Zschimmer \& Schwarz, & & \\
& $\quad$ Germany) & $1 \cdot 5$ & - \\
Water & MgSO $_{4}$ (Industrial Grade) & 3 & 5 \\
\hline
\end{tabular}

reported in table 1. Also the average chemical compositions of samples were determined by wet analytical method which are shown in table 2. For comparison, one kind of industrially used Iranian refractory grade magnesite selected as reference sample (MR) and its physical and chemical properties are reported in tables 1 and 2 .

\subsection{Flotation}

In this research, due to small liberation size i.e. $75 \mu \mathrm{m}$, reverse flotation method was used for magnesite purification from harmful minerals. After milling the sample, the resulting pulp with proper concentration was poured into the flotation cells (Denver flotation machine) and mixed by a rotor having a constant speed. The used chemicals were Armoflot 17, Armoflot 18 (Akzo chemicals, USA) and white oil as collector and foaming agent. In reverse flotation process, the wastes adhered to bubbles and transferred to the surface of the cell. Removing of the formed bubbles on the pulp surface continued until the ending of formation, growth of the bubbles and colour changes (Weiss 1985; Gence and Ozdag 1995). The resultant product from flotation process (AP) was chemically analysed and its mean composition is reported in table 2. Table 3 shows the optimum and stable conditions to achieve reverse magnesite flotation.

\subsection{Thermal analysis}

Thermal analysis which included thermogravimetry (TG) and differential thermal analysis (DTA), were done
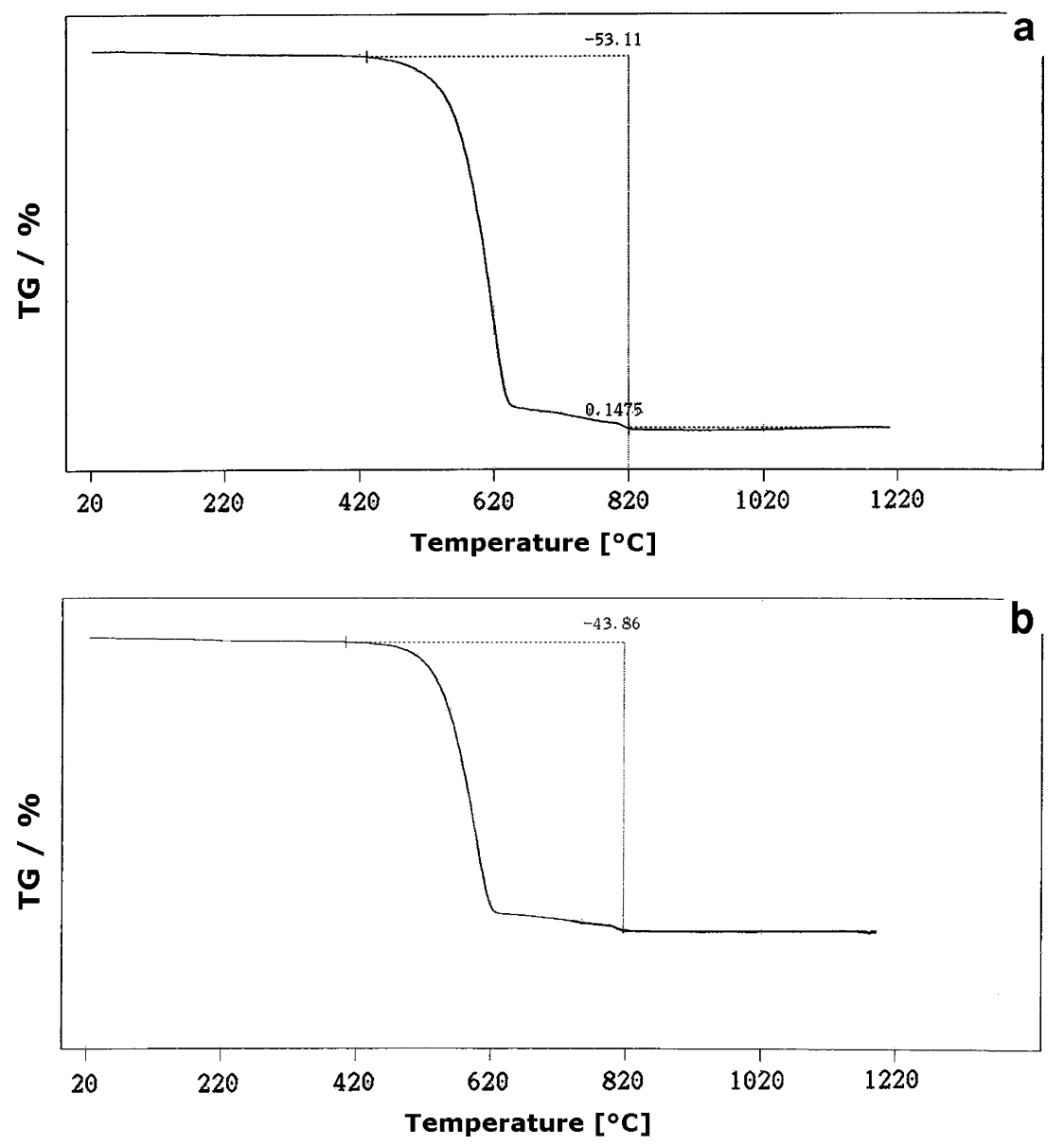

Figure 4. TG curves of magnesite ore samples: (a) As-received and (b) processed sample. 


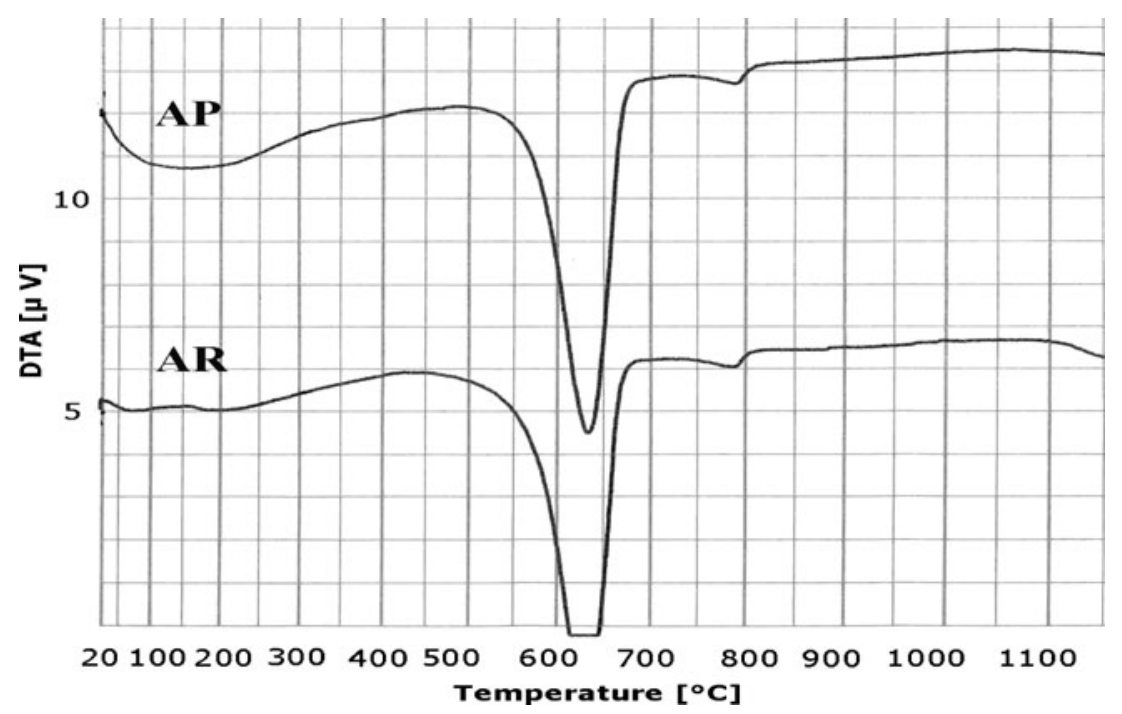

Figure 5. DTA curves of AR (as-received) and AP (processed) samples.

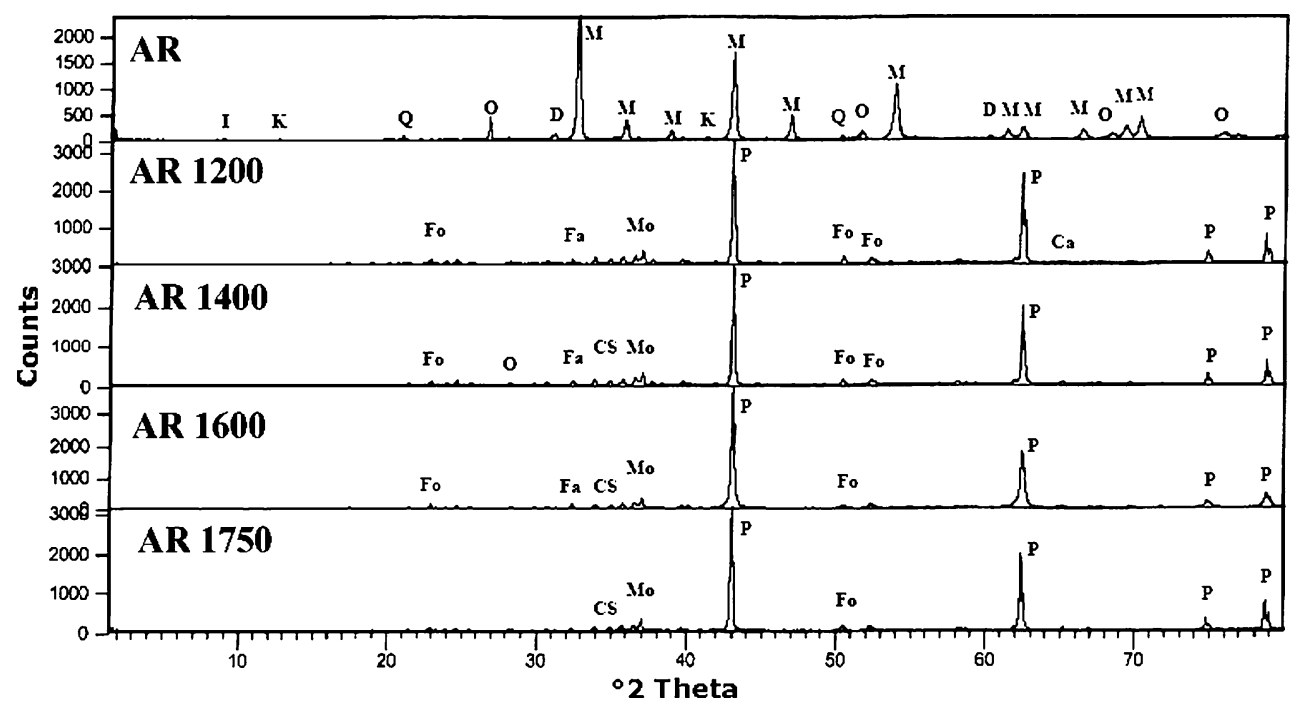

Figure 6. X-ray diffraction patterns of AR samples heated at different temperatures (M: magnesite, D: dolomite, O: olivine, Q: quartzite, K: kaolinite, I: illite, P: periclase, Fo: forsterite, Mo: monticellite, Ca: calcium oxide, Fa: fayalite, CS: calcium silicate).

by Shimadzu (Japan) and Netzsch (Germany) thermal analyser. The DTA test was done using $2 \mathrm{mg}$ sample in a platinum crucible and air atmosphere with a heating rate of $10 \mathrm{~K} / \mathrm{min}$ up to $1200{ }^{\circ} \mathrm{C}$. The TG test was performed using $50 \mathrm{mg}$ sample in an alumina cell and air atmosphere with a heating rate of $10 \mathrm{~K} / \mathrm{min}$ up to $1400{ }^{\circ} \mathrm{C}$.

\subsection{Phases evolution}

In this study, all phase investigations were performed by $\mathrm{Cu} \mathrm{K} \mathrm{K}_{\alpha} 1 \cdot 54 \AA$ X-ray, using D8 advanced Bruker AXS$\mathrm{GmbH}$ system. The mineralogical composition of AR, AP and MR samples was determined by X-ray diffractometry. In order to evaluate the phase variations at different temperatures, samples from the as-received and processed ores were heated at $1200,1400,1600$ and $1750{ }^{\circ} \mathrm{C}$, and soaked for $2 \mathrm{~h}$ at each temperature in alumina crucible situated in an electric furnace. Then the samples were crushed, ground and studied by X-ray diffractometry.

\subsection{Microstructural studies}

Microstructural study was performed using SEM/EDS Vega Tescan scanning electron microscope. For this purpose some AP aggregates were mounted and polished to prepare a suitable surface for electron microscopy studies. Then the sample was coated by a thin gold-platinum layer using a sputter coater. 


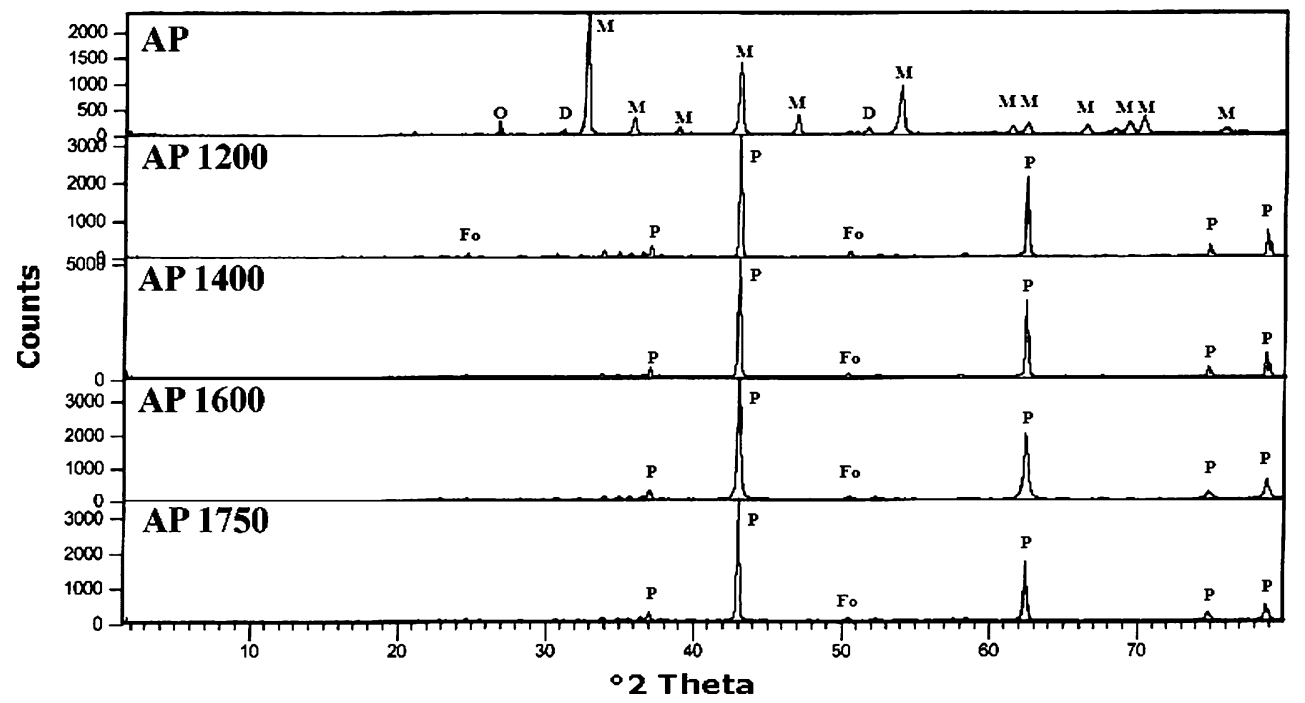

Figure 7. X-ray diffraction patterns of AP samples heated at different temperatures (M: magnesite, $\mathrm{D}$ : dolomite, O: olivine, $\mathrm{P}$ : periclase, Fo: forsterite).

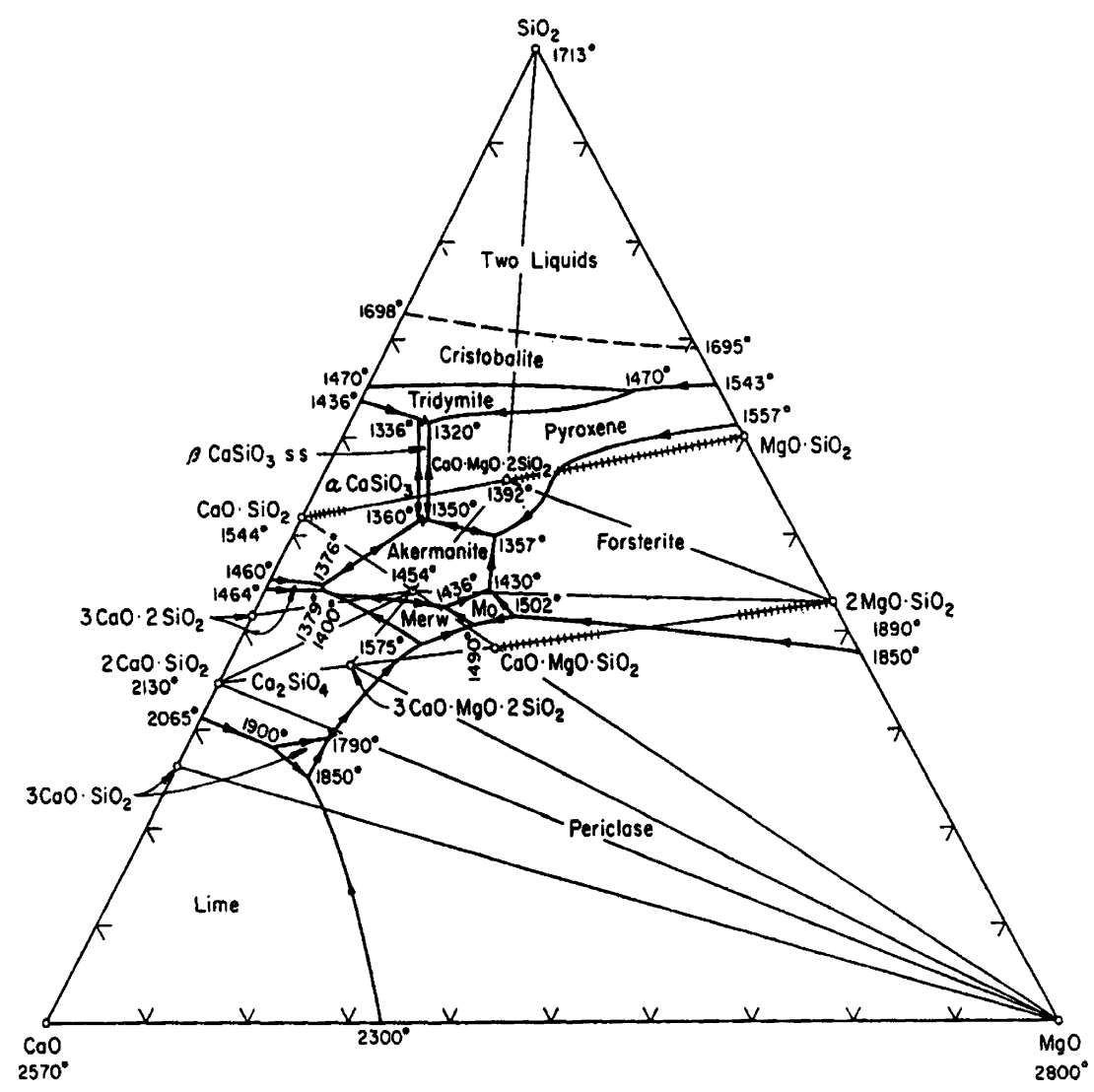

Figure 8. $\mathrm{MgO}-\mathrm{SiO}_{2}-\mathrm{CaO}$ ternary phase diagram.

\subsection{Refractories preparation and characterization}

In order to evaluate the applications of as-received and processed magnesite ores in refractory industry, samples in the form of refractory bricks and refractory ramming mixes were prepared. At first, $50 \mathrm{~kg}$ of each of the as-received and processed magnesite with particle size finer than $5 \mathrm{~mm}$ was preheated with a slow rate up to $1200{ }^{\circ} \mathrm{C}$ for $24 \mathrm{~h}$ in an electric furnace. Then the calcined materials were ground and mixed with 1.5 wt. $\% \mathrm{MgCl}_{2}$ as binder and 3 wt. $\%$ water and shaped in the form of briquettes by hydraulic pressing in a $4 \times 6$ cylindrical die at $700 \mathrm{kgf} / \mathrm{cm}^{2}$ pressure. 


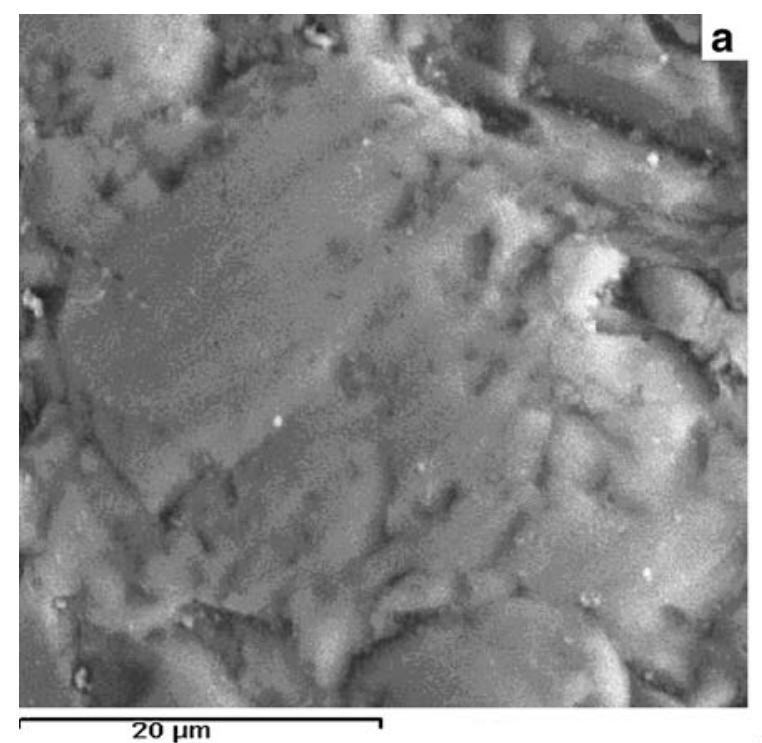

a

b

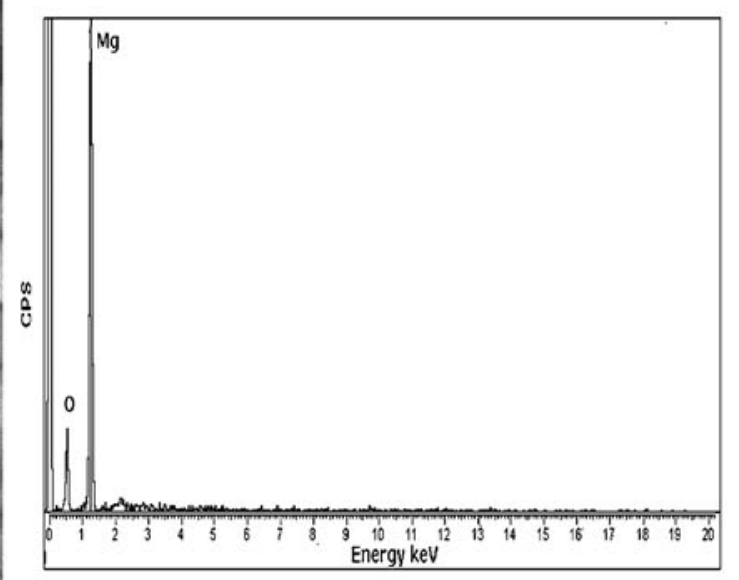

C
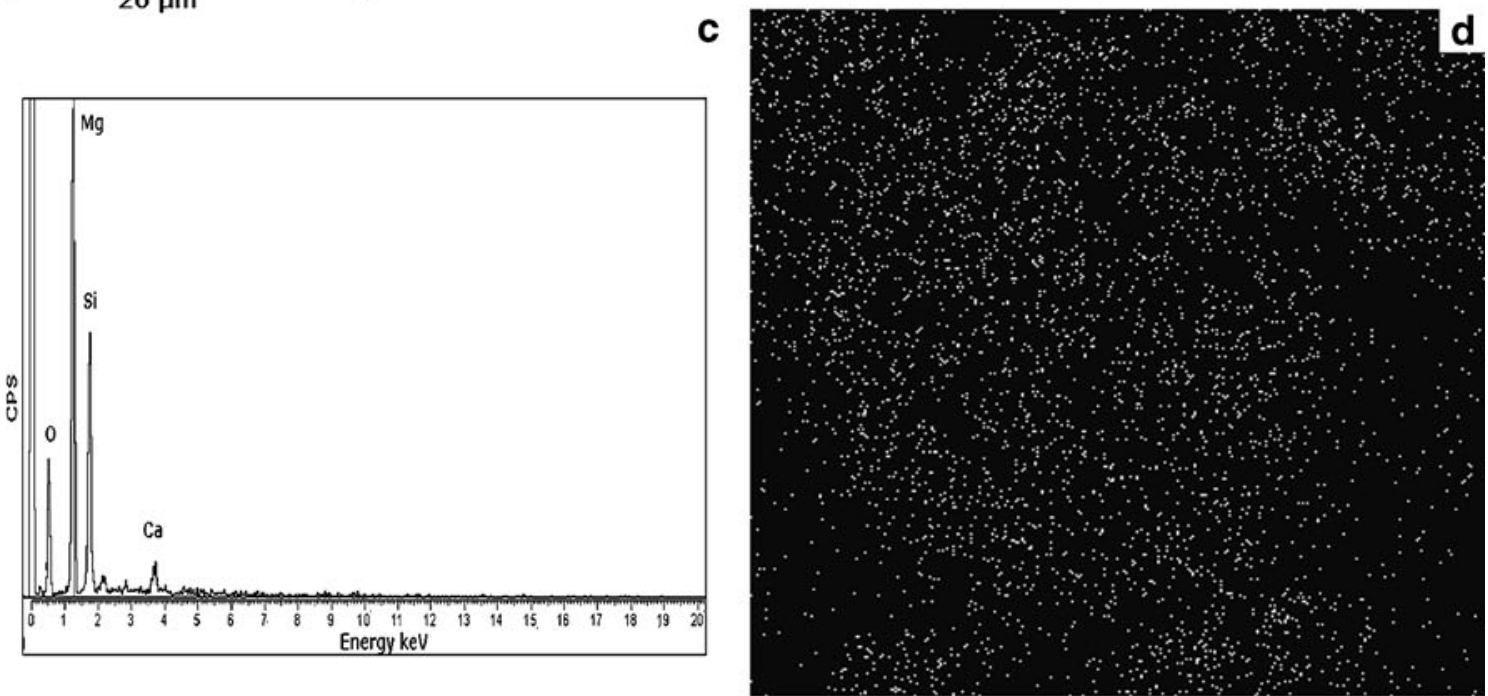

Mg
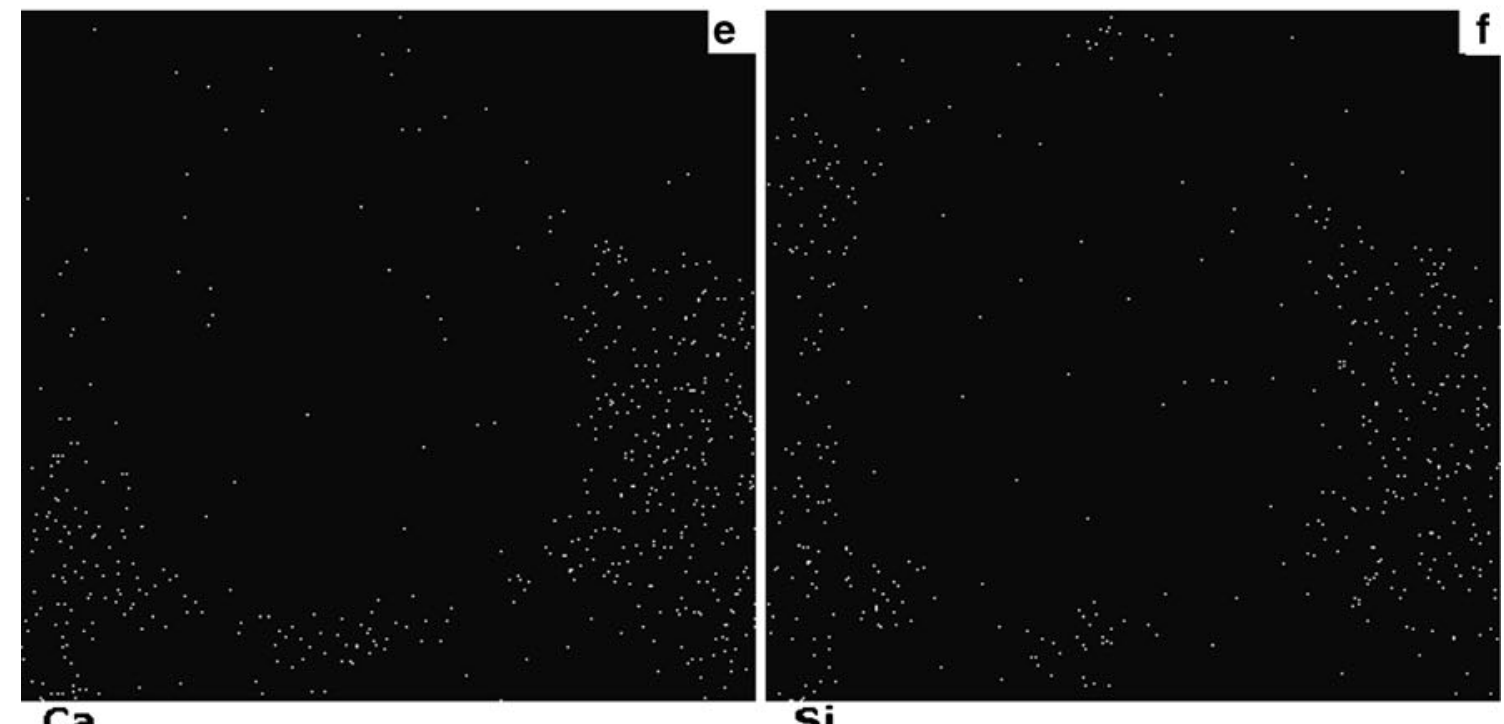

Si

Figure 9. Scanning electron micrographs of AP1750 sample: (a) micrograph of an aggregate, (b) EDS analysis of the aggregate, (c) EDS analysis of the grain boundary, (d) Mg MAP elemental distribution, (e) Ca MAP elemental distribution and (f) Si MAP elemental distribution. 
Then the briquettes were dried at room temperature and then heated for $24 \mathrm{~h}$ at $110{ }^{\circ} \mathrm{C}$. Finally these briquettes were placed in a gas furnace and heated up to $1700{ }^{\circ} \mathrm{C}$ with a slow heating rate for a period of $12 \mathrm{~h}$. The samples were kept at maximum temperature for a period of $15 \mathrm{~h}$ before cooling them to room temperature. The briquettes were then crushed and ground by jaw crusher and hammer mill and the crushed aggregates were evaluated for size by screening. The batch composition of magnesia refractory brick and ramming mix samples were prepared according to table 4 . Also for comparison, reference refractory samples were prepared by utilization of the commercial magnesia aggregates (MR) with the same formulations as in table 4. After mixing and aging of the batches, refractory brick samples were shaped by hydraulic pressing in a $4 \times 6$ cylindrical die at $1000 \mathrm{kgf} / \mathrm{cm}^{2}$ pressure. The samples were dried at room temperature and at $110{ }^{\circ} \mathrm{C}$ for $24 \mathrm{~h}$ and heated in a gas furnace with slow rate up to 1050 and $1550{ }^{\circ} \mathrm{C}$ and $5 \mathrm{~h}$ soaking at maximum temperature. Ramming mix samples were shaped according to BS 1902 (section 7:6, 1987) standard in $3 \times 3$ cylindrical dies and dried and heated in a similar way as brick samples.

Bulk density and apparent porosity of refractory samples measured according to DIN 51056 standard from samples heated at $1550{ }^{\circ} \mathrm{C}$ and cold crushing strength according to DIN 51067 standard from samples heated at 110,1050 and $1550{ }^{\circ} \mathrm{C}$. All results gained by calculating the mathematical mean of values from atleast 5-6 samples of each formulation.

\section{Results and discussion}

Figures $4 \mathrm{a}$ and $\mathrm{b}$ show the TG curves of $\mathrm{AR}$ and $\mathrm{AP}$ samples, respectively. From these figures it can be seen that a sharp weight loss occurred at $600-650{ }^{\circ} \mathrm{C}$ for both samples. The weight loss for AR and AP samples was equal to $53 \cdot 11 \%$ and $43 \cdot 86 \%$, respectively. Generally the heating weight loss of magnesite ores occurs due to the decomposition of magnesium carbonate to magnesium oxide and carbon dioxide at a temperature near to $600{ }^{\circ} \mathrm{C}$. In this reaction, $52 \cdot 38 \%$ weight loss basically occurred due to $\mathrm{CO}_{2}$ gas generation. The other factors affecting on the weight loss of magnesite ores are the presence of other carbonate materials, impurities and organic materials which are usually present in mineral ores (Birchal et al 2000). Figure 5 shows DTA curves of both samples. As this figure shows, a wide endothermic peak occurred in the range $250-450{ }^{\circ} \mathrm{C}$ which is related to evaporation of moisture and burning out of organic materials. But the major sharp peak occurred at $600-630{ }^{\circ} \mathrm{C}$ which was because of the decomposition of magnesite according to TG test data.

Figures 6 and 7 show the X-ray diffraction patterns of AR and AP samples after being heated at different temperatures. Mineralogical analyses (figure 6) of AR sample shows that this sample consists of magnesite $\left(\mathrm{MgCO}_{3}\right)$, quartzite $\left(\mathrm{SiO}_{2}\right)$, dolomite $\left(\mathrm{MgCa}\left(\mathrm{CO}_{3}\right)_{2}\right)$, olivine $\left(\mathrm{MgFeSiO}_{4}\right)$ and some weak picks which is related to clay minerals such as kaolinite and illite. Also AP sample consists of magnesite, dolomite and olivine according to figure 7.

During the heating of AR and AP samples to higher temperatures, the carbonate peaks disappear and periclase $(\mathrm{MgO})$ peaks appear. By increasing the temperature, the intensity of periclase picks increased (figures 6 and 7) but the intensity of calcium silicate phases was less in the AR samples than AP samples. Heating to $1200{ }^{\circ} \mathrm{C}$, the composition of phases in AR1200 changes to periclase $(M)$, forsterite $\left(M_{2} S\right)$, fayalite, monticellite (CMS), olivine and calcium oxide. However, by increasing the temperature further more to $1400{ }^{\circ} \mathrm{C}$ and above, the composition of phases in AP samples slightly changed particularly in calcium silicate phases. Finally the phases composition of AR1750 sample consisted of $\mathrm{M}, \mathrm{M}_{2} \mathrm{~S}$ and CMS. Heating the AP sample up to $1200{ }^{\circ} \mathrm{C}$, the phase composition consisted of $\mathrm{M}, \mathrm{M}_{2} \mathrm{~S}$ and CMS. With increasing the temperature to $1400{ }^{\circ} \mathrm{C}$ and above, the phase compositions slightly changed and the final product at $1750{ }^{\circ} \mathrm{C}$ (AP1750) contained periclase as a major phase and $\mathrm{M}_{2} \mathrm{~S}$ as a minor phase.

The major chemical components of AR sample after calcination at $1750{ }^{\circ} \mathrm{C}$ were $\mathrm{MgO}(\min .82 \%), \mathrm{SiO}_{2}(9 \cdot 3 \%)$ and $\mathrm{CaO}(3 \cdot 5 \%)$ and the lime $/ \mathrm{SiO}_{2}(\mathrm{C} / \mathrm{S})$ ratio was $0 \cdot 38$. According to $\mathrm{MgO}-\mathrm{CaO}-\mathrm{SiO}_{2}$ ternary phase diagram in figure 8 (Bergeron and Risbund 1984), the final phases composition of this sample consisted of periclase as major phase and some calcium silicate phases such as $\mathrm{M}_{2} \mathrm{~S}, \mathrm{CMS}$ and calcium silicates $\left(\mathrm{CS}, \mathrm{C}_{2} \mathrm{~S}\right.$ and $\mathrm{C}_{3} \mathrm{~S}$ ). However, due to the decrease in $\mathrm{CaO}$ and $\mathrm{SiO}_{2}$ and increase in $\mathrm{MgO}$ after reverse flotation process of magnesite ores, the presence of calcium silicate phases in AP1750 was less than that of the non-processed sample (AR1750). On the other hand, decreasing the $\mathrm{SiO}_{2}$ content of the magnesite raw

Table 5. Mechanical and physical properties of refractory brick and ramming mix samples.

\begin{tabular}{|c|c|c|c|c|c|c|c|}
\hline \multicolumn{2}{|l|}{ Refractory type } & \multicolumn{3}{|c|}{ Bricks } & \multicolumn{3}{|c|}{ Ramming mix } \\
\hline Aggregate type & & AR1750 & AP1750 & MR & AR1750 & AP1750 & MR \\
\hline \multirow[t]{3}{*}{ Cold crushing strength $(\mathrm{MPa})$} & $110^{\circ} \mathrm{C}$ & 13 & 13 & $14 \cdot 1$ & $11 \cdot 5$ & $11 \cdot 8$ & 12 \\
\hline & $1050^{\circ} \mathrm{C}$ & $14 \cdot 5$ & 15 & 15 & $11 \cdot 9$ & $11 \cdot 5$ & $11 \cdot 5$ \\
\hline & $1550^{\circ} \mathrm{C}$ & 42 & $45 \cdot 5$ & 46 & 34 & 37 & $39 \cdot 3$ \\
\hline Apparent porosity (\%) & & 19 & $17 \cdot 9$ & $17 \cdot 5$ & $28 \cdot 6$ & $25 \cdot 2$ & 22 \\
\hline Bulk density $\left(\mathrm{gr} / \mathrm{cm}^{3}\right)$ & & $2 \cdot 6$ & $2 \cdot 85$ & $2 \cdot 85$ & $2 \cdot 55$ & $2 \cdot 76$ & $2 \cdot 8$ \\
\hline
\end{tabular}


materials limited the formation of magnesium, calcium and iron silicate phases such as $\mathrm{M}_{2} \mathrm{~S}$, merwinite $\left(\mathrm{C}_{3} \mathrm{MS}_{2}\right)$, fayalite and calcium silicates. These minerals, especially $\mathrm{CMS}$, have lower melting temperatures $\left(1492{ }^{\circ} \mathrm{C}\right)$ than $\mathrm{MgO}\left(2840^{\circ} \mathrm{C}\right)$. Also the formation of their binary and ternary eutectic compositions (invariant points) such as $\mathrm{M}-\mathrm{M}_{2} \mathrm{~S}-\mathrm{CMS}\left(1502{ }^{\circ} \mathrm{C}\right)$, M-CMS$\mathrm{C}_{3} \mathrm{MS}_{2}\left(1492{ }^{\circ} \mathrm{C}\right)$ and $\mathrm{M}-\mathrm{C}_{2} \mathrm{~S}-\mathrm{C}_{2} \mathrm{~F}\left(1385^{\circ} \mathrm{C}\right)$ may have severe negative effects on refractory properties of magnesite raw materials (Spencer 1978). However, the presence of small amounts of calcium silicate phases can be effective in binding system formation of magnesia refractories and especially in the production and sintering of silicate bonded magnesia refractory bricks (Palco and Riguad 1993; Othman and Khalil 2005).

Figure 9a shows the scanning electron micrograph of an aggregate in the polished surface of AP1750 sample. Figure $9 \mathrm{~b}$ shows the EDS analysis of the main aggregate that consists of periclase phase. Figure 9c shows the EDS analysis of the grain boundary region. The presence of $\mathrm{Ca}$ and $\mathrm{Si}$ elements are clear in this figure. Figures $9 \mathrm{~d}-\mathrm{f}$ show the elemental distribution of $\mathrm{Mg}, \mathrm{Ca}$ and $\mathrm{Si}$ as in figure $9 \mathrm{a}$. As these figures show, the aggregate consists of periclase grains that are surrounded by grain boundaries formed by collection of calcium silicate phases.

The results of physical and mechanical properties measurements of refractory samples are reported in table 5. As the results show, the apparent porosity and bulk density values for AP brick and ramming mix samples are near to the values of reference samples. Also there is the same state for CCS results. The strength of samples dried at $110{ }^{\circ} \mathrm{C}$ normally is caused by chemical binders setting. After heating these samples to $1050{ }^{\circ} \mathrm{C}$ the chemical bonds disappeared and also no ceramic bonds were created by heating at this temperature. So the strength values of samples heated at $1050{ }^{\circ} \mathrm{C}$ were equal to or slightly less than those of the samples heated at $110{ }^{\circ} \mathrm{C}$. But heating the samples in $1550{ }^{\circ} \mathrm{C}$ caused the fusion of low melting point silicate phases and formation of glassy phase which is placed among the periclase grains. These glassy phases solidify during the cooling step and form the grain boundaries of refractory matrix. Thus ceramic bond generates in the form of silicate bond and the strength values of refractory samples heated in $1550{ }^{\circ} \mathrm{C}$ significantly increase. On the other hand, by increasing the amounts of calcium silicate phases in magnesia refractories due to the use of high $\mathrm{SiO}_{2}$ and $\mathrm{CaO}$ content magnesia, the density and CCS values decrease and apparent porosity increases (GolestaniFard et al 1995; Othman and Khalil 2005). So it can be seen that the physical and mechanical properties of AP1750 sample are equal or near to those of the reference sample.

\section{Conclusions}

In this research the effects of reverse flotation process on chemical composition, phases, microstructural and refractory properties of magnesite ores from Iranian Afzal Abad mine located in the eastern part of Iran were investigated. Flotation process was applied to reduce the $\mathrm{CaO}$ and $\mathrm{SiO}_{2}$ contents of the samples. Also phase studies showed that the formation of calcium and iron silicate phases in the final processed calcined aggregates is limited. The physical and mechanical properties of shaped and unshaped refractory products made from processed aggregates are comparable to the products made from commercial aggregates. Finally it can be concluded that the processed aggregates are suitable for using in the production of silicate bonded magnesia refractory bricks and a variety of monolithic refractories especially magnesia ramming, gunning and tundish mixes.

\section{Acknowledgements}

The authors wish to express their appreciation for the technical support provided by Iran Refractory Material Production Company (IRMPCo.) and the laboratories of School of Mining Engineering, University of Tehran, School of Metallurgy and Materials Engineering, Iran, University of Science and Technology (IUST) and Khorasan Science and Technology park (Ceramic Pilot).

\section{References}

Ahmed I, Padhyang P K and Chandra D 1990 Res. Ind. 3528

Aksel C, Kasap F and Sesver A 2005 Ceram. Int. 31121

Bergeron C G and Risbund S H 1984 Introduction to phase equilibria in ceramics (Ohio: American Ceramic Society) p. 522

Birchal V S S, Rocha S D F and Ciminelli V S T 2000 Miner. Eng. 131629

Chen G and Tao D 2004 Int. J. Miner. Process. 74343

Covacic D W R and Clarke J A 1991 Sampling equipment and techniques, part of the sampling of bulk materials (London, UK: Institution of Mechanical Engineering) p. 123

Dolatabadi M 2000 An introduction to east Iranian magnesite mines, Internal Report of Iran Refractory Materials Production Company, pp. 145

Gence N and Ozdag H 1995 Int. J. Miner. Process. 4337

Golestani-Fard F 1997 Interceram 6455

Golestani-Fard F, Fotouhi B and Marghosian V 1995 UNITECR 95 Japan refractory congress (Tokyo, Japan: Technical Association of Refractories) p. 202

Hoseini A 1988 Refractory raw materials (Tehran: Amir Kabir Publications)

Jankanovic V and Vumberkovic Z 1992 Interceram 4187

Nishino T 1999 Taikabutsu Overseas 114

Othman A G M and Khalil N M 2005 Ceram. Int. 311117

Ozkan S G 2002 Miner. Eng. 1599

Palco S and Riguad M 1993 J. Can. Ceram. Soc. 162253

Palco S and Riguad M 2002 Metallurgy refractories and environment conference (Slovakia: Technical University of Kosice) p. 275

Ryder A 1993 Trans. Ind. Ceram. Soc. 5288

Santana A N and Peres A E C 2001 Miner. Eng. 14107

Shikano H 1998 Refractories handbook (Japan: Technical Association of Refractories) p. 127

Spencer D R 1978 First conference on refractory materials (London: The Institute of Refractories Engineers) p. 209

Yaghubpur A and Hassannejad A A 2006 J. Sci. I. R. Iran 17147

Weiss N L 1985 SME Mineral processing handbook (Colorado, USA: Society of Mining Engineering of AIME) p. 14 